\title{
Pendekatan Kontekstual Sebagai Upaya Meningkatkan Kemampuan Siswa Kelas IX C SMP Xaverius 2 Jambi dalam Mengapresiasi Cerita Pendek
}

\author{
Rosmauli Sirait \\ Guru SMP Xaverius 2 Jambi
}

\begin{abstract}
Bahasa Indonesia is a subject that must be followed by students from elementary school to college, including mastery of language skills that are reading, speaking, listening and writing developed Integrated. Class action research conducted to improve students ' ability to appreciate short stories with a contextual approach in class IX C of Xaverius 2 Jambi first secondary school. The study was conducted over two cycles. Each cycle takes three stages of the process, ranging from planning, action and reflection. In the first cycle, student learning results still show an average value of 56.95, while the level of activity and the creativity of students have qualitatively obtained an average value of 67.25 with the number of students who received less (below 50) value of $50 \%$ Of the number of participants/classes (18 persons). In the second cycle, indicating an increase in the number of students who gained sufficient value (55 - 70), which is from 9 (nine) people to 18 people for all categories of assessments and students who obtained a good value of $25 \%$ (9 people). Thus, the results gained indicate that through a contextual approach, students ' ability to appreciate short stories increased as expected.
\end{abstract}

Key words: cotextual approach; Improve students ' abilities; Short story

\section{PENDAHULUAN}

Salah satu tujuan pembelajaran sastra di sekolah adalah agar siswa mampu menikmati, memahami dan memanfaatkan karya sastra untuk mengembangkan kepribadian, memperkuat wawasan kehidupan serta meningkatkan pengetahuan dan kemampuan berbahasa. Misalnya dengan memetik makna (etika, religi dan budaya) yang tertuang dalam sastra. Oleh karena itu pengajaran sastra dapat memberikan siswa pemahaman yang mendalam tentang manusia dan peristiwa-peristiwa yang melingkupinya.

Kurang berhasilnya pengajaran sastra di sekolah dipengaruhi oleh beberapa faktor, di antaranya: 1) rendahnya minat baca siswa terhadap buku-buku sastra; 2) kurangnya sarana pendukung (perpustakaan) dalam pengadaan buku-buku yang menunjang; 3) kurang tepatnya guru dalam menentukan metode/pendekatan pembelajaran dalam mengajar sastra yang mengakibatkan pembelajaran sastra kurang menarik.

Menyadari pentingnya esensi pendidikan siswa terhadap pengajaran sastra, diharapkan guru dapat memotivasi siswa dengan menumbuh kembangkan minat baca siswa. Salah satu sarana untuk meningkatkan minat baca tersebut adalah dengan memilih bacaan yang menarik. Bacaan yang menarik biasanya adalah bacaan yang mudah difahami alur ceritanya, dengan tema yang diangkat dari kehidupan sehari-hari, berupa cerita pendek atau buku kumpulan cerita pendek.

Dalam upaya meningkatkan apresiasi sastra melalui apresiasi cerita pendek dan menemukan unsurunsur intrinsik dengan pendekatan kontekstual diharapkan dapat membantu guru mengaitkan antara materi pembelajaran dengan situasi dunia nyata siswa dan mendorong siswa untuk membuat hubungan antara pengetahuan yang dimiliki dengan penerapan kehidupan mereka sebagai anggota keluarga, anggota masyarakat, dan warga sekolah sehingga pembelajaran menjadi lebih bermakna.

Tindakan yang dilakukan dalam upaya memecahkan masalah pembelajaran dalam rangka meningkatkan kemampuan mengapresiasi cerita pendek di kelas IX C SMP Xaverius 2 Jambi, penulis menggunakan pendekatan kontekstual. Hal ini dilakukan mengingat bahwa melalui pendekatan kontekstual siswa menjadi subyek dalam proses pembelajaran, di mana: 1) Siswa belajar dalam kehidupan nyata, sehingga pengetahuan yang diperoleh siswa akan bermakna dalam kehidupan. 2) Siswa terlatih untuk berfikir lebih mendalam. 3) Siswa terlatih untuk aktif, kritis dan kreatif. 4) Pembelajaran berpusat pada siswa, bukan pada guru. 5) Siswa bukan menghafal tetapi praktek. 6) Kegiatan proses belajar bukan mengajar tetapi kegiatan belajar mengarahkan siswa untuk memecahkan masalah.

Dengan demikian penggunaan pendekatan kontekstual menghindarkan kejenuhan siswa dalam belajar, menghindarkan proses belajar yang monoton, dan klasik.

Berdasarkan uraian tersebut di atas, penulis mencoba menerapkan model pembelajaran dengan pendekatan kontekstual dalam mengapresiasi cerita pendek sebagai upaya meningkatnya apresiasi sastra Indonesia di kelas IX C SMP Xav.erius 2 Jambi.

\section{Landasan Teori \\ Pengajaran Membaca Sastra}

Membaca adalah suatu proses yang dilakukan serta dipergunakan oleh pembaca untuk memperoleh pesan yang disampaikan penulis melalui media bahas tulis. Komponen pengajaran membaca tertuang dalam kompetensi dasar kurikulum tingkat satuan pendidikan (KTSP).

Tujuan pembelajaran sastra adalah agar siswa memperoleh pengalaman dan pengetahuan tentang sastra, yaitu memperoleh pengalaman dalam mengapresiasi sastra.

Terdapat tiga hal penting yang harus diperhatikan dalam upaya pencapaian tujuan pengajaran sastra, khususnya dalam pengajaran cerita pendek, yaitu:

1. Siswa hendaknya memperoleh kesadaran yang lebih baik terhadap dirinya sendiri, orang lain dan kehidupan sekitarnya sehingga mereka bersikap terbuka, rendah hati, peka perasaan kritiknya 
terhadap tingkah laku pribadi, orang lain, serta masalah-masalah kehidupan di sekitarnya.

2. Siswa hendaknya dapat memperoleh kesenangan dari membaca dan mempelajari puisi atau cerita pendek sehingga tumbuh keinginan untuk membaca dan mempelajari puisi atau cerita pendek pada waktu senggang

3. Siswa hendaknya memperoleh pengetahuan dan pengertian dasar tentang puisi atau cerita pendek sehingga tumbuh keinginan memadukan dengan pengalaman pribadinya yang diperoleh di sekolahnya di sekolah ini dan mendatang.

Dengan uraian di atas, maka seorang guru dituntut mengajarkan sastra dengan baik, dan bukan hanya berupa pengetahuan saja melainkan mampu mengajarkan sastra berupa pengalaman dalam arti mengapresiasikannya dengan baik.

Tujuan pengajaran apresiasi cerita pendek di dalam kurikulum tingkat satuan pendidikan (KTSP) terdapat dalam standar kompetensi dan kompetensi dasar sesuai dengan Peraturan Pemerintah Nomor: 19 Tahun 2005, tentang Standar Nasional Pendidikan, Bab V, Standar Lulusan, pasal 25 ayat (3) dijelaskan bahwa kompetensi lulusan untuk mata pelajaran bahasa (termasuk bahasa Indonesia) menekankan pada kemampuan membaca dan menulis yang sesuai dengan jenjang pendidikan. Dalam hal membaca, pada akhir pendidikan di tingkat SMP/MTs, peserta didik diharapkan telah membaca sekurang-kurangnya 9 (sembilan) buku sastra dan 3 (tiga) buku non sastra.

Penjelasan tentang standar isi dan standar kelulusan diatur dalam peraturan pemerintah nomor 24 tahun 2006 mengenai Panduan Penyusunan Kurikulum Tingkat Satuan Pendidikan dan Silabus Bahasa Indonesia.

Sementara itu sastra adalah satu bentuk sistem tanda karya seni yang menggunakan media bahasa. Jadi pembelajaran sastra ditekankan pada kenyataan bahwa sastra merupakan salah satu bentuk seni yang dapat diapresiasi.

\section{Kemampuan Apresiasi}

Siswa dapat dikatakan mampu mengapresisasi sastra bila siswa tersebut dapat menanggapi, memahami, menghayati karya sastra. Hal ini merupakan sesuai dengan pendapat Drs. Abd. Rochman $\mathrm{H} \mathrm{A}$, bahwa kemampuan apresiasi sastra menyangkut kesiapan dalam menanggapi, memahami, menghayati dan keterampilan mengapresisai karya sastra. Selain itu bahwa tingkat kemampuan apresiasi ini lebih penting dilihat dari perangkat sastra sebagai berikut:

1. Memperluas, memperdalam, menghayati daya imajinasi siswa

2. Menyediakan bahan-bahan yang sesuai

3. Meningkatkan taraf paresiasi dan kepuasan dalam membaca

4. Melengkapi daya rangsang intelek dan jiwa

5. Mendorong perkembangan daya intelek, perasaan, imajinasi fiksi dan menafsirkan.

Dari pendapat diatas dapat disimpulkan bahwa kemampuan apresiasi sastra merupakan kemampuan memahami, menghayati dan menanggapi karya sastra serta menanggapi, menghayati dan menciptakan tingkah laku ideal dari isi cerpen tersebut.

\section{Pengertian Cerita Pendek}

Cerita pendek merupakan salah satu jenis cerita rekaan yang berisi rangkaian peristiwa berdasarkan unsur-unsur yang mendukungnya. Unsur-unsur tersebut saling berhubungan satu sama lainnya. Cerita pendek merupakan cerita yang bersifat rekaan yang pendek, yang mengisahkan peristiwa secara rasional (Rusyana, 1980). Muchtar Lubis (1981), mengatakan bahwa cerita pendek ada yang terdiri dari 5000 kata, ada juga yang mencapai 40000 kata. Berdasarkan batasan tersebut diatas dapat disimpulkan bahwa cerita pendek merupakan cerita rekaan yang mengisahkan peristiwa rasional dengan jumlah kata terdiri dari 5000 sampai 40 000 kata.

\section{Pendekatan Kontekstual}

Pendekatan kontekstual merupakan konsep belajar yang membantu guru mengaitkan antara materi yang diajarkan dengan situasi dunia nyata siswa dan mendorong siswa membuat hubungan antara pengetahuan yang dimilikinya dengan penerapan dalam kehidupan nyata mereka sebagai anggota keluarga dan masyarakat (pendekatan Kontekstual; Depdiknas, 2003). Dengan konsep itu, hasil belajar diharapkan dapat lebih bermakna bagi siswa.

Pendekatan kontekstual memiliki tujuh komponen, yaitu konstruktivisme, bertanya, inkuiri, masyarakat pelajar, penilaian authentic, pemodelan, refleksi (Dirjen Pendidikan Dasar dan Menengah, 2003 ; 1-5).

Penerapan pendekatan kontekstual dalam kelas cukup mudah, secara garis besar langkah-langkahnya sebagai berikut:

1. Kembangkan pemikiran bahwa siswa akan belajar lebih bermakna dengan cara bekerja sendiri, menemukan sendiri, mengkonstruksi sendiri pengetahuan dan keterampilan barunya.

2. Laksanakan sejauh mungkin kegiatan inkuiri untuk semua topik.

3. Kembangkan sifat ingin tahu siswa dengan bertanya.

4. Ciptakan masyarakat belajar (belajar dalam kelompok-kelompoknya)

5. Hadirkan model sebagai contoh pembelajaran.

6. Lakukan refleksi di akhir pertemuan

7. Lakukan penilaian sebenarnya dengan berbagai variasi

Menurut Zohorik, yang dikutip Direktorat Jenderal Pendidikan Dasar dan Menengah (2003), terdapat lima elemen yang harus diperhatikan dalam praktek pembelajaran kontekstual, yaitu:

1. Pengaktifan pengetahuan yang ada

2. Pemerolehan pengetahuan baru dengan cara mempelajari secara keseluruhan dahulu, kemudian memperhatikan detailnya.

3. Pemahaman pengetahuan, yaitu dengan cara menyusun:

a. Konsep sementara (hipotesis)

b. Melakukan sharing dengan orang lain agar mendapat tanggapan (validasi),

c. Atas tanggapan tersebut, konsep itu di revisi dan dikembangkan 
4. Mempraktekkan pengetahuan dan pengalaman tersebut

5. Melakukan refleksi terhadap strategi pengembangan pengetahuan tersebut.

Karakteristik pembelajaran dengan pendekatan kontekstual adalah sebagai berikut:

1. Kerja sama

2. Saling menunjang

3. Menyenangkan, tidak membosankan

4. Belajar dengan bergairah

5. Pendekatan terintegrasi

6. Menggunakan berbagai sumber

7. Siswa aktif

8. Sharing dengan teman

9. Siswa kritis, guru kreatif

10.Dinding kelas dan lorong-lorong penuh dengan hasil karya siswa, peta-peta, gambar-gambar, artikel, humor, dll.

11.Laporan kepada orang tua bukan hanya buku rapor, tetapi hasil karya siswa, laporan kurikulum, karangan siswa, dll.

Pendekatan kontekstual dapat dilaksanakan tanpa harus mengubah kurikulum dan tatanan yang ada.

\section{METODE PENELITIAN}

\section{Setting dan Karakteristik Subyek Penelitian}

Penelitian ini dilakukan di kelas IX C SMP Xaverius 2 Jambi semester gasal Tahun Pelajaran 2015/2016. Penelitian dilakukan secara kolaborasi antara dua orang, yaitu guru bahasa Indonesia dan mahasiswa yang mengadakan penelitan. Jumlah siswa di kelas IX C terdiri dari 20 orang siswa laki-laki dan 16 orang siswa perempuan. Karakteristik kelas cenderung sama dengan kelas-kelas lainnya, artinya tingkat kemampuan/prestasi belajar kelas tersebut sama dengan kelas lainnya, demikian pula keadaan sosial ekonominya.

Pembelajaran bahasa Indonesia yang terdiri dari empat keterampilan yaitu membaca, menyimak, berbicara dan menulis bukanlah hal baru, hanya saja kemampuan memahami bervariasi sehingga penetuan KKM (Kriteria Ketuntasan Maksimal) setiap aspek berbeda.

\section{Prosedur Penelitian}

Penelitian ini dilakukan pada tanggal 20 Oktober 2015 s.d 8 Nopember 2016. Pelaksanaannya diimplementasikan dalam kegiatan PBM dengan melibatkan seorang guru bahasa yang bertindak sebagai observer. Penelitian dilaksanakan dalam dua siklus, masing-masing selama $2 \times 40$ menit. Setiap siklusnya hanya dilakukan satu tindakan dan observasi. Siklus pertama dianggap mengalami kegagalan. Kegagalan tersebut diperbaiki pada pelaksanaan siklus kedua dengan harapan mendapatkan hasil optimal sesuai dengan rencana penelitian.

\section{Tahap Observasi dan Evaluasi}

Observasi dilaksanakan oleh observer bersamaan dengan proses pembelajaran. Observasi dilakukan untuk memperoleh data kualitatif maupun kuantitatif melalui pelaksanaan evaluasi menggunakan alat bantu lembar observasi dan alat evaluasi. Evaluasi dilakukan pada proses pembelajaran untuk setiap siklus.

Kriteria keberhasilan (indikator) untuk kreativitas siswa dan tingkat kemampuan siswa dalam menemukan unsur-unsur intrinsic (tema, latar dan penokohan) cerpen menggunakan komponen-komponen pendekatan kontekstual di ukur berdasarkan skala sebagai berikut:

- Tingkat kreatifitas siswa:

$$
\begin{array}{ll}
\geq 80 \% & =\text { tinggi } \\
60-79 \% & =\text { sedang } \\
\leq 59 \% & =\text { rendah }
\end{array}
$$

- Tingkat keberhasilan siswa:

$$
\begin{array}{ll}
91-100 & =\text { baik sekali } \\
75-90 & =\text { baik } \\
55-74 & =\text { cukup } \\
\leq 54 & =\text { kurang }
\end{array}
$$

\section{Tahap Analisis dan Refleksi}

Prosedur analisis data dilakukan melalui tahapan:

- Reduksi data, jika terdapat data yang tidak diperlukan

- Penyederhanaan data

- Tabulasi data

- Penyimpulan data

Hasil analisis data akan digunakan sebagai bahan refleksi. Observer satu dan observer lainnya mendiskusikan hasil pengamatan tindakan yang telah dilakukan.

Hal-hal yang dilakukan adalah:

(1) Menganalisis tentang tindakan yang telah dilaksanakan

(2) Mengulas dan menjelaskan perbedaan rencana dengan tindakan yang telah dilaksanakan

(3) Melakukan intervensi pemaknaan dan penyimpulan data yang diperoleh serta melihat hubungan antara teori dan rencana yang telah ditetapkan

\section{HASIL DAN PEMBAHASAN Siklus I}

Hasil belajar siswa pada standar kompetensi membaca yaitu menemukan tema, latar dan penokohan dalam cerpen pada suatu buku kumpulan cerpen dengan rentang nilai 0 sampai 100 , diperoleh data sebagai berikut:

\section{Hasil belajar siswa}

Tabel 1. Data Hasil Belajar Siswa

\begin{tabular}{ccccccc}
\hline No & Kelompok & Kerjasama & Keseriusan & Hasil karya & Rata-rata & Keterangan \\
\hline 1 & A & 40 & 50 & 60 & 50 & Kurang \\
2 & B & 60 & 60 & 60 & 60 & Cukup \\
3 & C & 50 & 60 & 50 & 53,33 & Kurang \\
4 & D & 70 & 60 & 70 & 66,67 & Cukup \\
5 & E & 65 & 55 & 60 & 60 & Cukup \\
6 & F & 45 & 60 & 50 & 51,67 & Kurang \\
\hline
\end{tabular}


Dari tabel di atas dapat dilihat bahwa kelompok A, $C$ dan $F$ mendapat nilai rata-rata kurang $(\leq 55)$ dikarenakan kelompok-kelompok tersebut masih terlihat kurang kompak pada pelaksanaan diskusi dalam menganalisis masalah, walaupun mereka dapat menyelesaikan tugas dan mempresentasikan hasil karyanya.

Tabel 2. Data Hasil Belajar Siswa

\begin{tabular}{cccc}
\hline No & Nilai & Frekuensi absolut & Frekuensi relatif \\
\hline 1 & $\leq 50$ & 18 & 50 \\
2 & $55-70$ & 9 & 25 \\
3 & $75-90$ & 9 & 25 \\
4 & $\geq 90$ & - & - \\
& & 36 & 100
\end{tabular}

Sumber: Daftar nilai kelas IX C SMP Xaverius 2 Jambi, pelajaran bahasa Indonesia, dalam kompetensi dasar menemukan tema, latar dan penokohan dalam cerpen pada suatu buku kumpulan cerpen. Tahun pelajaran 2015/2016.

Data tabel tersebut menunjukkan bahwa jumlah siswa yang mendapat nilai kurang (40-50) sebanyak 18 orang atau $50 \%$ dari jumlah siswa dalam kelas penelitian, sedangkan siswa yang mendapat nilai cukup dan baik masing-masing sebanyak 9 orang atau $25 \%$

\section{Kreativitas dan aktivitas siswa dalam KBM}

tingkat kreativitas dan aktivitas siswa selama proses pembelajaran dengan kompetensi dasar menemukan tema, latar dan penokohan, disajikan dalam tabel 3 berikut :

Tabel 3. Kreativitas dan Aktivitas Siswa dalam KBM

\begin{tabular}{lllc}
\hline No & \multicolumn{1}{c}{ Kreativitas dan aktivitas } & $\%$ & Keterangan \\
\hline 1 & Konsentrasi siswa mengikuti KBM & 60 & Sedang \\
2 & Antusias siswa dalam mengikuti KBM & 75 & Sedang \\
3 & Aktivitas dan kreativitas siswa dalam mengerjakan tugas & 75 & Sedang \\
4 & Aktivitas siswa selama diskusi & 59 & Rendah \\
\hline
\end{tabular}

Aktivitas dan kreativitas siswa dalam diskusi ternyata masih rendah dikarenakan kurangnya keberanian siswa dalam mengajukan pertanyaan dan menanggapi hasil pekerjaan kelompok lain, tetapi dalam kegiatan lainnya (no 1 s.d 3) siswa sudah cukup baik.

\section{Kemampuan Guru dalam Perencanaan dan Pelaksanaan Pembelajaran}

Data kemampuan guru membuat perencanaan dan pelaksanaan pembelajaran Hasil pengamatan observer terhadap kemampuan guru pelaksana tindakan diperoleh data sebagai berikut:

Tabel 4. Kemampuan guru membuat perencanaan dan melaksanakannya

\begin{tabular}{llcc}
\hline No & \multicolumn{1}{c}{ Aspek yang dinilai } & $\%$ & Keterangan \\
\hline 1 & Persiapan pembelajaran & 75 & Baik \\
2 & Penyajian KBM & 75 & Baik \\
\hline
\end{tabular}

Keterangan: lembar observasi terlampir

\section{Siklus II}

\section{Hasil belajar siswa}

Hasil belajar siswa pada kompetensi dasar menemukan tema, latar dan penokohan dengan rentang nilai 0 sampai 10 pada siklus kedua ini, diperoleh data sebagai berikut:

Tabel 5. Data Hasil Siswa

\begin{tabular}{ccccccc}
\hline No & Kelompok & Kerjasama & Keseriusan & Hasil karya & Rata-rata & Keterangan \\
\hline 1 & A & 50 & 60 & 50 & 53,33 & Kurang \\
2 & B & 70 & 60 & 60 & 63,33 & Cukup \\
3 & C & 60 & 65 & 60 & 61,67 & Cukup \\
4 & D & 75 & 70 & 75 & 73,33 & Cukup \\
5 & E & 70 & 65 & 60 & 65,00 & Cukup \\
6 & F & 60 & 65 & 60 & 61,67 & Cukup \\
\hline
\end{tabular}

Data tabel tersebut menunjukkan bahwa perolehan nilai hasil belajar siswa secara umum menunjukkan adanya peningkatan dibanding dengan perolehan pada siklus pertama, kecuali kelompok $A$ yang kurang memuaskan. 
Tabel 6. Data hasil belajar siswa

\begin{tabular}{llllll}
\hline No & & Nilai & & Frekuensi absolut & Frekuensi relatif \\
\hline 1 & $40-50$ & & 9 & 25 & \\
2 & $55-70$ & 18 & 50 & \\
3 & $75-90$ & 9 & - & 25 & \\
4 & $\geq 95$ & 36 & 100 & \\
& & & & & 100 \\
\hline
\end{tabular}

Sumber: Daftar nilai kelas IX C pelajaran bahasa Indonesia dalam kompetensi dasar membaca dalam menemukan tema, latar dan penokohan dalam cerpen. Tahun Pelajaran 2015/2016

Sesuai dengan tabel diatas, hasil belajar siswa menunjukkan adanya peningkatan secara kuantitas. Siswa yang memperoleh hasil cukup dengan baik mencapai $75 \%$ atau lebih banyak dari siswa yang memperoleh nilai kurang atau hanya $25 \%$.

\section{Kreativitas dan Aktivitas Siswa}

kreativitas dan aktivitas siswa selama mengikuti proses pembelajaran, ditunjukkan dalam tabel berikut ini.

Tabel 7. Kreativitas dan aktivitas siswa dalam KBM

\begin{tabular}{llcc}
\hline No & Kreativitas dan aktivitas & $\%$ & Keterangan \\
\hline 1 & Konsentrasi siswa mengikuti KBM & 80 & Tinggi \\
2 & Antusias siswa dalam mengikuti KBM & 85 & Tinggi \\
3 & Aktivitas dan kreativitas siswa dalam mengerjakan tugas & 80 & Tinggi \\
4 & Aktivitas dan kreativitas siswa dalam diskusi & 75 & Sedang \\
\hline
\end{tabular}

Konsentrasi, antusias dan aktivitas dan kreativitas siswa dalam mengerjakan tugas maupun dalam diskusi, mengalami peningkatan dibanding dengan perolehan pada siklus pertama. Aktivitas dan kreativitas siswa dalam diskusi masih belum optimal dan masih banyak ditingkatkan ke arah yang lebih baik lagi

\section{Kemampuan Guru dalam Perencanaan dan Pelaksanaan Pembelajaran}

Data yang diperoleh berdasarkan pengamatan observer terhadap tingkat kemampuan guru membuat perencanaan dan mengimplementasikannya dalam proses pembelajaran, disajikan dalam table berikut.

Tabel 8. Tingkat kemampuan guru

\begin{tabular}{lllll}
\hline & No & \multicolumn{1}{c}{ Aspek yang dinilai } & $\%$ & Keterangan \\
\hline 1 & Persiapan pembelajaran & 80 & Baik \\
2 & Penyajian KBM & 80 & Baik \\
\hline
\end{tabular}

Keterangan: lembar observasi terlampir

\section{Pembahasan}

Hasil belajar siswa pada siklus pertama belum menunjukkan hasil seperti yang diharapkan. Hal ini dapat terlihat dari perolehan nilai yang hanya mencapai rata-rata 56,95 sedangkan nilai untuk aktivitas dan kreativitas siswa rata-rata 67,25 , dengan persentase siswa yang mendapat nilai kurang sebanyak 18 orang atau setengah (50\%) dari jumlah peserta/kelas. Keadaan demikian diduga sebagai akibat dari pelaksanaan diskusi kelompok yang tidak sungguhsungguh serta kurang kompak dalam pembagian tugas kelompok. Walaupun demikian, hal ini kiranya dapat dimaklumi mengingat bahwa cara dan pendekatan belajar sesuai dengan pendekatan ini masih belum benar-benar difahami oleh seluruh siswa.

Dari hasil tersebut di atas, kemudian guru memberikan saran agar pada saat diskusi kelompok dan pengerjaan tugas dapat dilaksanakan dengan lebih kompak sesuai dengan pembagian tugas. Oleh karena itu pada siklus kedua, semua kelompok dapat meningkatkan nilai rata-rata menjadi 63,05 untuk kategori hasil belajar siswa dengan rata-rata 80 untuk kategori aktivitas dan kreativitas siswa.

Hasil pelaksanaan tindakan pada siklus kedua, menunjukkan adanya peningkatan hasil belajar siswa maupun tingkat kreativitas dan aktivitas siswa. Dari 50\%
(18 orang siswa) yang memperoleh nilai kurang, sembilan orang di antaranya berhasil memperbaiki nilai dengan kategori cukup, sehingga relatif komposisi siswa yang mendapat nilai cukup menjadi 50\% (18 orang), dan siswa yang mendapat nilai baik menjadi 9 orang (25\%). Dengan demikian pula dalam hal kreativitas dan aktivitas siswa, menunjukkan adanya peningkatan yang cukup besar, dari sedang dan rendah pada siklus pertama menjadi tinggi pada siklus kedua.

\section{SIMPULAN}

Berdasarkan hasil penelitian dan pengolahan data, dapat disimpulkan bahwa:

1. Hasil belajar siswa mengalami peningkatan sesuai dengan yang diharapkan.

2. Dalam menganalisis cerpen siswa belum bisa membaca cepat yang diperlukan untuk menemukan unsur-unsur intrinsic (tema, latar dan penokohan) dalam suatu buku kumpulan cerpen.

3. Aktivitas dan kreativitas siswa dalam KBM pada siklus kedua lebih baik dari pada siklus pertama.

\section{DAFTAR PUSTAKA}

Badudu, J S. 1977. Sari Kesusastraan Indonesia. Pustaka Prima. Bandung 
Depdiknas. 2003. Pendekatan Kontekstual (Contextual Teaching and Learning (CTL). Jakarta. Ditjen Dikdasmen.

Lubis, Mochtar. 1981. Teknik Mengarang. Jakarta: Kurnia Esa.

Mulyana, Yoyo, $\underline{\text { dkk. }}$ 1998. Sanggar Sastra. Depdiknas. Jakarta.

Ridwan, Saadah. 1977. Penelitian Tindakan Kelas bagi Guru. BEP0 Bandung.

Rusyana, Y (1984). Bahasa dan Sastra dalam Gamitan Pendidikan. Bandung: Diponegoro

Slamet Harjasujana, Ahmad, dkk. 1977. Membaca 2. Depdiknas. Jakarta

Tim Penyusun. 1989. Kamus Besar Bahasa Indonesia. 1989. Balai Pustaka. Jakarta.

Zulfahnur, Z E. 1977. Sastra Bandingan. Depdiknas. Jakarta. 